\title{
Design, Synthesis and Antifungal Activity of 3-substituedmethylenethiochroman-4-one Derivatives
}

\author{
Xinghua Zhang \\ Key Laboratory for Pharmaceutical Quality Control of Hebei Province \\ College of Pharmaceutical Science, Hebei University, Baoding, Hebei, 071002, China \\ E-mail: zhangxinghua20061984@126.com
}

Zhengyue Ma

Key Laboratory for Pharmaceutical Quality Control of Hebei Province

College of Pharmaceutical Science, Hebei University, Baoding, Hebei, 071002, China

Email: mazhengy@126.com

Gengliang Yang (Corresponding author) \& Yajun Zheng

Key Laboratory for Pharmaceutical Quality Control of Hebei Province

College of Pharmaceutical Science, Hebei University, Baoding, Hebei, 071002, China

We are grateful for financial support by the National Natural Science Foundation of China (Grant Nos. 20375010, and 20675084), Program for Science and Technology Development of Hebei Province (Grant Nos. $06276479 B$ and $07276407 D$ ).

\begin{abstract}
Four new 3-substituedmethylenethiochroman-4-one derivatives were prepared from (z)-3-(chloromethylene)thiochroman-4-one. They were characterized by analytical and spectral methods. In vitro antifungal activities of these synthesized compounds were evaluated against ten species of fungi, and the results showed that (e)-3-chloromethylene compound exhibited a similar good activity against fungi to (z)-3-chloromethylene compound. (Z)-3-substituedaminomethylene compound also exhibited antifungi activity to some extent.
\end{abstract}

Keywords: Antifungal activity, Thiochromanones, 3-substituedmethylenethiochroman-4-one

\section{Introduction}

Over the last three decades there has been a dramatic increase in the incidence of fungal infections. Discovery of new drugs for the treatment of systemic mycoses is a major challenge in infectious disease research.

Thiochromanones had been reported to possess important biological activities(Nakazumi, H., 1984). Nakib T A et al reported that thiochromanone derivatives had antifungal activities (Nakib, T. A. 1990). 3-Benzylidene (Qi Ping, 2004), 3-Mannich base (Zhu Quanhong, 2000), 3-bromo (QI Ping, 2003), 2,3,3a,4-tetrahydrothiochromeno[4,3-c]pyrazole derivatives (Ma Zhengyue, 2008) and 6H-thiochromeno[4,3-b]quinoline derivatives (Wang Ge, 2010) had been synthesized and reported to have antifungal activities. In our laboratory, (z)-3-halomethylene of thiochromanone derivatives were synthesized and proved with good antifungal activity (Fang Baoling, 2010; Tian Wei, 2010). To discover new 3-substituedmethylene analogues with good antifungal activity, herein, four new compounds from the (z)-3-(chloromethylene)thiochroman-4-one were designed, synthesized and screened for their antifungal activity. The synthetic route was outlined in the Scheme 1.

\section{Experimental}

\subsection{Chemistry}

Substituted benzenethiols (chemically pure) were from SHOUERFU LLC (ZHEJIANG, China). All other materials were commercially available and used as received unless otherwise noted. Mass spectral data were obtained by LC-MSD XCT Trap G2446A (Agilent Technologies, USA). Melting points were determined SGW 
X-4 microscopic melting point (Shanghai Precision \& Scientific Instrument Co., Ltd, China). IR spectra were recorded in potassium bromide on FTIR-8400S (SHIMADZUCO-RPORATION, Kyoto, Japan). ${ }^{1} \mathrm{H}$ NMR spectra were recorded in $\mathrm{CDCl}_{3}$ on Bruker Avance III $600 \mathrm{~Hz}$ spectrometer. The chemical shifts are reported as parts per million $(\delta \mathrm{ppm})$ from $\left(\mathrm{CH}_{3}\right)_{4} \mathrm{Si}(\mathrm{TMS})$ as an internal standard. Elemental analysis was performed on a Carlo Erba-1106 instrument and the results were in acceptable range.

\subsection{Preparation of compound (z)-3-(chloromethylene)-6-chlorothiochroman-4-one (3)}

Sodium methoxide $(20.0 \mathrm{mmol})$, ethyl formate $(10.0 \mathrm{mmol})$ and toluene $(50 \mathrm{~mL})$ were mixtured into a round-bottomed flask $(250 \mathrm{~mL})$, then a solution of compound $1(5.0 \mathrm{mmol})$ in toluene $(20 \mathrm{~mL})$ were dropwise added over $20 \mathrm{~min}$ in ice bath. The mixture was stirred for $12 \mathrm{~h}$ at the temperature $<10{ }^{\circ} \mathrm{C}$. The organic phase was extracted twice with water $(2 \times 20 \mathrm{~mL})$, the combined aqueous phase was adjusted to about 4 with $\mathrm{HCl}$, maintaining the temperature at $<5{ }^{\circ} \mathrm{C}$, the solid precipitated was filtered, abundantly washed with water, then air dried. The crude product was recrystallized from $95 \%$ (v/v) EtOH to afford the compound 2.

compound $2(5.0 \mathrm{mmol})$ and acetyl chloride $(7.5 \mathrm{mmol})$ was dissolved in dichloromethane $(40 \mathrm{~mL})$ in a sealed tube, and the mixture was stirred at $50{ }^{\circ} \mathrm{C}$ for $2 \mathrm{~h}$. After the the solution was extracted with $0.5 \mathrm{~mol} / \mathrm{L} \mathrm{Na}_{2} \mathrm{CO}_{3}$ $(2 \times 15 \mathrm{~mL})$, the organic layer was was dried over anhydrous $\mathrm{MgSO}_{4}$ and evaporated in vacuo to give the crude product. The crude product was purified by silica-gel column chromatography (dichloromethane: petroleum ether=1:10 (v/v) ) to afford the compound 3 (Tian Wei, 2010; Fang Baoling, 2010), compound 2: yield, 83\%; compound 3: yield, $74 \%$.

\subsection{Preparation of compound (e)-3-(chloromethylene)-6-chlorothiochroman-4-one (4)}

compound $3(5.0 \mathrm{mmol})$ was dissolved in methanol $(60 \mathrm{~mL})$ in a round bottomed flask $(150 \mathrm{~mL})$ irradiating $20 \mathrm{~h}$ under $60 \mathrm{~W}$ UV lamp, solvent was evaporated in vacuo to give the crude product. The crude product was purified by silica-gel column chromatography (dichloromethane: petroleum ether $=1: 10(\mathrm{v} / \mathrm{v})$.) to afford the pure compound 4 .

\subsection{1 (E)-6-Chloro-3-(chloromethylene)thiochroman-4-one (4)}

Yellow solid. Yield: $30 \%$; mp: $91-93{ }^{\circ} \mathrm{C}$. UV-vis $(\mathrm{MeOH}) \lambda_{\max }: 250 \mathrm{~nm} ;{ }^{1} \mathrm{H}$ NMR $\left(600 \mathrm{MHz}, \mathrm{CDCl}_{3}\right) \delta \mathrm{ppm}$ : 8.19 (d, $J=1.68 \mathrm{~Hz}, 1 \mathrm{H}, \mathrm{Ar}-\mathrm{H}), 7.39$ (dd, $J=8.35,1.76 \mathrm{~Hz}, 1 \mathrm{H}, \mathrm{Ar}-\mathrm{H}), 7.25$ (d, $J=8.43 \mathrm{~Hz}, 1 \mathrm{H}, \mathrm{Ar}-\mathrm{H}), 6.76$ (s, $1 \mathrm{H}, \mathrm{C}=\mathrm{CH}-), 3.87\left(\mathrm{~s}, 2 \mathrm{H}, \mathrm{SCH}_{2}\right)$. IR $(\mathrm{KBr}): 1670(\mathrm{C}=\mathrm{O}), 1593(\mathrm{C}=\mathrm{C}) \mathrm{cm}^{-1}$. MS (APCI): $\mathrm{m} / z 244.9[\mathrm{M}+\mathrm{H}]^{+}$, $246.9[\mathrm{M}+2+\mathrm{H}]^{+}$. Anal. Calcd for $\mathrm{C}_{10} \mathrm{H}_{6} \mathrm{Cl}_{2} \mathrm{OS}: \mathrm{C}, 49.00 ; \mathrm{H}, 2.47 ; \mathrm{S}, 13.08$. Found: C, 48.96; H, 2.42; S, 13.12.

\subsection{Preparation of compound (Z)-6-Chloro-3-((dimethylamino)methylene)thiochroman-4-one (5)}

$\mathrm{NH}\left(\mathrm{CH}_{3}\right)_{2} \cdot \mathrm{HCl}(6.0 \mathrm{mmol})$ and $\mathrm{N}\left(\mathrm{CH}_{2} \mathrm{CH}_{3}\right)_{3}(15.0 \mathrm{mmol})$ were dissolved in $\mathrm{CH}_{2} \mathrm{Cl}_{2}(25 \mathrm{~mL})$ and cooled to $0{ }^{\circ} \mathrm{C}$, then a solution of compound $3(5.0 \mathrm{mmol})$ in $\mathrm{CH}_{2} \mathrm{Cl}_{2}(5 \mathrm{~mL})$ were added, dropwise, and the mixture was stirred at $0{ }^{\circ} \mathrm{C}$ for $2.5 \mathrm{~h}$. After the solution was extracted with water $(2 \times 20 \mathrm{~mL})$, the organic layer was dried over anhydrous $\mathrm{MgSO}_{4}$ and evaporated in vacuo to give the crude product. The crude product was recrystallized from 95\% (v/v) EtOH to afford the compound 5.

\subsection{1 (Z)-6-Chloro-3-((dimethylamino)methylene)thiochroman-4-one (6)}

Yellow solid. Yield: $87 \%$; mp: $123-125^{\circ} \mathrm{C}$. UV-vis $(\mathrm{MeOH}) \lambda_{\max }: 248 \mathrm{~nm} ;{ }^{1} \mathrm{H}$ NMR $\left(600 \mathrm{MHz}, \mathrm{CDCl}_{3}\right) \delta \mathrm{ppm}$ : $8.06(\mathrm{~d}, J=2.35 \mathrm{~Hz}, 1 \mathrm{H}, \mathrm{Ar}-\mathrm{H}), 7.61$ (s, $1 \mathrm{H}, \mathrm{C}=\mathrm{CH}-), 7.25$ (dd, $J=8.33,2.39 \mathrm{~Hz}, 1 \mathrm{H}, \mathrm{Ar}-\mathrm{H}), 7.19$ (d, $J=8.34$ $\mathrm{Hz}, 1 \mathrm{H}, \mathrm{Ar}-\mathrm{H}), 4.01\left(\mathrm{~s}, 2 \mathrm{H}, \mathrm{SCH}_{2}\right), 3.17\left(\mathrm{~s}, 6 \mathrm{H}, \mathrm{C}\left(\mathrm{CH}_{3}\right)_{2}\right)$. IR $(\mathrm{KBr}): 1637(\mathrm{C}=\mathrm{O}), 1579(\mathrm{C}=\mathrm{C}) \mathrm{cm}^{-1}$. MS (APCI): $m / z 253.9[\mathrm{M}+\mathrm{H}]^{+}, 255.9[\mathrm{M}+2+\mathrm{H}]^{+}$. Anal. Calcd for $\mathrm{C}_{12} \mathrm{H}_{12}$ ClNOS: C, 56.80; H, 4.77; N, 5.52; S, 12.64. Found: C, 56.83; H, 4.80; N, 5.47; S, 12.60 .

\subsection{Preparation of compound 3-(phenylthiomethylene)thiochroman-4-one (6a-6b)}

Substituted benzenethiols $(6.0 \mathrm{mmol})$ and $\mathrm{NaH}(12.5 \mathrm{mmol})$ were added in dry THF $(25 \mathrm{~mL})$ and cooled to $0{ }^{\circ} \mathrm{C}$, then a solution of compound $3(5.0 \mathrm{mmol})$ in THF $(8 \mathrm{~mL})$ were added, dropwise. After stirring $2 \mathrm{~h}$, added crushed ice slowly to the mixture and removed excess $\mathrm{NaH}$, then added water $(60 \mathrm{~mL})$, the solid precipitated was filtered, abundantly washed with water, then air dried. The crude product was purified by silica-gel column chromatography (dichloromethane: petroleum ether $=1: 50(\mathrm{v} / \mathrm{v})$ ) to afford the compound $6 \mathrm{a}$ and $6 \mathrm{~b}$.

\subsection{1 (Z)-6-Chloro-3-(p-tolylthiomethylene)thiochroman-4-one (6a)}

Green solid. Yield: $34 \%$; mp: 111-113 ${ }^{\circ} \mathrm{C}$. UV-vis $(\mathrm{MeOH}) \lambda_{\max }: 254 \mathrm{~nm} ;{ }^{1} \mathrm{H}$ NMR $\left(600 \mathrm{MHz}, \mathrm{CDCl}_{3}\right) \delta \mathrm{ppm}$ : 8.07 (d, $J=2.41 \mathrm{~Hz}, 1 \mathrm{H}, \mathrm{Ar}-\mathrm{H}), 7.88$ (s, $1 \mathrm{H}, \mathrm{C}=\mathrm{CH}-), 7.39$ (d, $J=8.06 \mathrm{~Hz}, 2 \mathrm{H}, \mathrm{Ar}-\mathrm{H}), 7.33$ (dd, $J=8.43,2.38$ $\mathrm{Hz}, 1 \mathrm{H}, \mathrm{Ar}-\mathrm{H}), 7.25(\mathrm{~d}, J=10.07 \mathrm{~Hz}, 1 \mathrm{H}, \mathrm{Ar}-\mathrm{H}), 7.21(\mathrm{~d}, J=7.94 \mathrm{~Hz}, 2 \mathrm{H}, \mathrm{Ar}-\mathrm{H}), 3.93\left(\mathrm{~s}, 2 \mathrm{H}, \mathrm{SCH}_{2}\right), 2.38(\mathrm{~s}$, $\left.3 \mathrm{H}, \mathrm{CH}_{3}\right)$. IR (KBr): 2923, $2852\left(\mathrm{CH}_{3}\right), 1683(\mathrm{C}=\mathrm{O}), 1635(\mathrm{C}=\mathrm{C}) \mathrm{cm}^{-1}$. MS (APCI): $m / z 333.0[\mathrm{M}+\mathrm{H}]^{+}, 335.9$ 
$[\mathrm{M}+2+\mathrm{H}]^{+}$. Anal. Calcd for $\mathrm{C}_{17} \mathrm{H}_{13} \mathrm{ClOS}_{2}: \mathrm{C}, 61.34 ; \mathrm{H}, 3.94 ; \mathrm{S}, 19.27$. Found: $\mathrm{C}, 61.37 ; \mathrm{H}, 3.90 ; \mathrm{S}, 19.31$.

2.3.2 (E)-6-Chloro-3-(p-tolylthiomethylene)thiochroman-4-one (6b)

Green solid. Yield: $30 \%$; mp: $104-106{ }^{\circ} \mathrm{C}$. UV-vis $(\mathrm{MeOH}) \lambda_{\max }: 254 \mathrm{~nm} ;{ }^{1} \mathrm{H}$ NMR $\left(600 \mathrm{MHz}, \mathrm{CDCl}_{3}\right) \delta \mathrm{ppm}$ : $8.12(\mathrm{~d}, J=2.41 \mathrm{~Hz}, 1 \mathrm{H}, \mathrm{Ar}-\mathrm{H}), 7.43(\mathrm{~d}, J=8.09 \mathrm{~Hz}, 2 \mathrm{H}, \mathrm{Ar}-\mathrm{H}), 7.35-7.31(\mathrm{~m}, 2 \mathrm{H}, \mathrm{Ar}-\mathrm{H}), 7.25$ (d, $J=8.39 \mathrm{~Hz}$, $1 \mathrm{H}, \mathrm{C}=\mathrm{CH}-), 7.21(\mathrm{~d}, J=7.95 \mathrm{~Hz}, 2 \mathrm{H}, \mathrm{Ar}-\mathrm{H}), 3.87\left(\mathrm{~d}, J=0.75 \mathrm{~Hz}, 2 \mathrm{H}, \mathrm{SCH}_{2}\right), 2.38\left(\mathrm{~s}, 3 \mathrm{H}, \mathrm{CH}_{3}\right) . \mathrm{IR}(\mathrm{KBr})$ : 2921, 1456, 1394 $\left(\mathrm{CH}_{3}\right), 1683(\mathrm{C}=\mathrm{O}), 1635(\mathrm{C}=\mathrm{C}) \mathrm{cm}^{-1}$. MS (APCI): $\mathrm{m} / z 333.0[\mathrm{M}+\mathrm{H}]^{+}, 335.9[\mathrm{M}+2+\mathrm{H}]^{+}$. Anal. Calcd for $\mathrm{C}_{17} \mathrm{H}_{13} \mathrm{ClOS}_{2}$ : C, 61.34; H, 3.94; S, 19.27. Found: C, 61.30; H, 3.90; S, 19.20.

\subsection{Antifungal Activity in Vitro}

In vitro antifungal activities were determined by double dilution method, the Minimum inhibitory concentration (MIC) were determined in accordance with the methods of the National Committee for Clinical Laboratory Standards (Marcelo C. Murgu' a, 2008). C. parapsilosis, C. glabrata, C. albicas, C. tropicalis, C. neoformans, C. Krusei, E. floccosum, M. gypseum, A. niger, S. schenekn were used as tested fungi for this study. Fluconazole was used as the reference drugs for positive control. The tested compounds were dissolved in $\operatorname{DMSO}(1 \mathrm{~mL})$, then the required concentrati- ons $(128,64,32,16,8,4,2,1,0.5,0.25,0.125 \mu \mathrm{g} / \mathrm{mL})$ were obtained by two fold serial dilution. The fungi were incubated and adjusted to a final concentration of $0.5 \times 10^{4}-2.5 \times 10^{4} \mathrm{CFU} / \mathrm{mL}$. $\mathrm{MIC}_{100}$ values were determined by visual observation after 2-7 $\mathrm{d}$ of incubation.

\section{Results and discussion}

\subsection{Structure elucidation}

The structures of the target compounds synthesized were established by mass spectroscopy, elemental analysis, ${ }^{1} \mathrm{H}-\mathrm{NMR}$ spectral data and NOE spectral data. The configuration of compounds 3 and 4 were assigned by their ${ }^{1} \mathrm{H}$ NMR spectra and ${ }^{1} \mathrm{H}-{ }^{1} \mathrm{H}$ NOE spectra. For compound 4, NOE correlations were observed from $\mathrm{H}$ of $-\mathrm{C}=\mathrm{CHCl}$ to $\mathrm{H}$ of $-\mathrm{SCH}_{2}$, but there was no correlation from $\mathrm{H}$ of $-\mathrm{C}=\mathrm{CHCl}$ to $\mathrm{H}$ of $-\mathrm{SCH}_{2}$ - on compound 3, as shown in Figure 1. The NOE spectra confirmed the compound 3 was $Z$-configuration and the compound 4 was E-configuration (see Figure 2).

During the synthesis of compound 5, only one product was obtained in the reaction. In order to determine its structure, NOE spectra was also studied. The ${ }^{1} \mathrm{H}$ NMR spectrum of compound $\mathbf{5}$ revealed three singlet signals at $\delta 3.17,4.01$ and 7.61 characteristic for $\mathrm{H}$ of $-\mathrm{N}\left(\mathrm{CH}_{3}\right)_{2}, \mathrm{H}$ of $-\mathrm{SCH}_{2}-$ and $\mathrm{H}$ of $-\mathrm{C}=\mathrm{CHCl}$, respectively. $\mathrm{NOE}$ correlations were observed from $\mathrm{H}$ of $-\mathrm{C}=\mathrm{CHCl}$ to $\mathrm{H}$ of $-\mathrm{SCH}_{2}$, but there was no correlation from $\mathrm{H}$ of $-\mathrm{C}=\mathrm{CHCl}$ to $\mathrm{H}$ of $-\mathrm{SCH}_{2}-$, as shown in Figure 1. These NOE's confirmed the absolute E-configuration of structure 5 (see Figure 2).

During the synthesis of compound 6 , there was no selectivity to the compound $6 \mathrm{a}$ and $6 \mathrm{~b}$, they were generated at the same time. Their structure were also confirmed by ${ }^{1} \mathrm{H}$ NMR spectra and NOE correlations. NOE correlations were observed from $\mathrm{H}$ of $-\mathrm{C}=\mathrm{CHCl}$ to $\mathrm{H}$ of $-\mathrm{SCH}_{2}$ - on compound $5 \mathrm{~b}$, and there was no correlation from $\mathrm{H}$ of $-\mathrm{C}=\mathrm{CHCl}$ to $\mathrm{H}$ of $-\mathrm{SCH}_{2}-$ of compound $5 \mathrm{a}$, as shown in Figure 1. The NOE spectra of compound 5 were also shown in Figure 2.

\subsection{Antifungal Activity in vitro}

The results of antifungal activities in vitro were shown in Table 1. In order to discover new active compound, structure optimization of compound 3 were operated. Compound 4 as $E$-isomers of 3 was prepared, but the result of antifungal activity indicated that there was no apparent difference between 3 and 4 . When chloromethylene was replaced with phenylthiomethylene and dimethylaminomethylene respectively, compound 5, 6a, and $6 \mathrm{~b}$ were synthesized. The tested result showed that dimethylaminomethylene derivative 5 had antigungal activity to some extent. Compound 5 had the best activity when against C.neoformans, its MIC was a similar to Fluconazole. However, phenylthiomethylene derivatives $6 \mathrm{a}$ and $6 \mathrm{~b}$ had no antifungal activity against most of the tested fungi. $6 \mathrm{a}$ and $6 \mathrm{~b}$ had the weak bioactive only against C.neoformans and C.Krusei.

In conclusion, 3-chloromethylene derivatives had good antifungal activity and other substitued 3-methylene derivatives either had lower activity or no acivity. The result should encourage us to design and synthesize more potent antifungal agents. Further biological evaluation of the compounds is in progress.

\section{References}

Nakazumi H.,Ueyama T. \& Kitao T. (1984). Synthesis and antibacterial of thioflavones and related compounds. Journal of Heterocyclic Chemisry, 1, 193-196.

Nakib, T. A., Bezjak, V. \& Meegan, M. J. (1990). Synthesis and antifungal activity of some 3-benz- 
ylidenechroman-4-ones, 3-benzylidenethiochroman-4-ones and 2-benzylidene-1-tetralones. European Journal of Medical Chemistry, 5, 455-462.

QI Ping, JIN Yinghua, GUO Chun \& FANG Lin. (2004). Synthesis of 3-benzylthiochromanones and their in vitro antifungal activity. Chinese Journal of New Drugs. 13, 141-143.

Zhu Quanhong, Fang Lin \& Zhang Guoliang. (2000). Synthesis and Antifungal Activities of the Mannich Baes of Thiochromanones Derivatives. Chinese Journal of Medicinal Chemistry, (10) 1-3.

Qi Ping, JIN Yinghua, Guo Chun \& Fang Lin. (2003). Syntheses and the antifungal activity of 3-bromo-4-thiochrom(an)ones. Chinese Journal of Medical Chemistry, 13, 205-207.

Ma Zhengyue, Yang Gengliang, Yan Guoying, Zhu Shiguo \& Guan Li. (2008). Synthesis of 2, 3, 3a, 4-tetrahydrothiochromeno[4, 3-c]pyrazoles derivatives and their antifungal activity in vitro. Chinese Journal of Medicinal Chemistry, 18, 170-174.

Wang Ge, Yang Gengliang, Ma Zhengyue, Tian Wei, Fang Baoling \& Li Linbo. (2010). Synthseis and antifungal activity of some 6H-thiochromeno[4,3-b]quinolines. International Journal of Chemistry, 1, 19-25.

Fang Baoling, Ma Zhengyue, Yang Gengliang, Wang Ge, Tian Wei \& Li Linbo. (2010). Synthesis and antifungal activity of (z)-3-(bromomethylene)thiochroman-4-ones. International Journal of Chemistry, 1, 143-146.

Tian Wei, Ma Zhengyue, Yang Gengliang, Wang Ge, Fang Baoling \& Li Linbo. (2010). Synthesis and antifungal activity of (z)-3-chloromethylenethiochroman-4-ones. Organic Chemistry : An Indian Journal, 1, 8-12.

Murguı'a, Marcelo C. \& Machuca, Laura M. (2008). Synthesis and Properties of Novel Antifungal Gemini Compounds Derived from N-Acetyl Diethanolamines. Journal of Surfactants and Detergent, 11, 223-230.

Table 1. Antifungal activity of compounds synthesized in vitro

\begin{tabular}{ccccccccccc}
\hline Compound & \multicolumn{10}{c}{$\mathrm{MIC}(\mu \mathrm{g} / \mathrm{mL})$} \\
\cline { 2 - 11 } & $\mathrm{Cp}$ & $\mathrm{Cg}$ & $\mathrm{Ca}$ & $\mathrm{Ct}$ & $\mathrm{Cn}$ & $\mathrm{CK}$ & $\mathrm{Ef}$ & $\mathrm{Mg}$ & $\mathrm{An}$ & $\mathrm{Ss}$ \\
\hline $\mathbf{3}$ & 2 & 16 & 4 & 4 & 4 & 32 & 2 & 16 & $>64$ & 4 \\
$\mathbf{4}$ & 2 & 32 & 4 & 8 & 4 & 16 & 4 & 16 & $>64$ & 4 \\
$\mathbf{5}$ & 32 & $>64$ & 32 & 64 & 4 & 64 & 32 & 64 & 32 & 64 \\
$\mathbf{6 a}$ & $>64$ & $>64$ & $>64$ & $>64$ & 4 & 32 & $>64$ & $>64$ & $>64$ & $>64$ \\
$\mathbf{6 b}$ & $>64$ & 64 & $>64$ & $>64$ & 8 & 64 & $>64$ & $>64$ & $>64$ & $>64$ \\
Flu & 4 & 16 & 0.5 & 2 & 4 & 64 & $>64$ & 64 & $>64$ & $>64$ \\
\hline
\end{tabular}

Abbreviations: Cp, C.parapsilosis; Cg, C.glabrata; Ca, C.albicas; Ct, C.tropicalis; Cn, C.neoformans; CK,

C.Krusei; Ef, E.floccosum; Mg, M.gypseum; An, A.niger; Ss, S.schenekn; Flu, Fluconazole. 


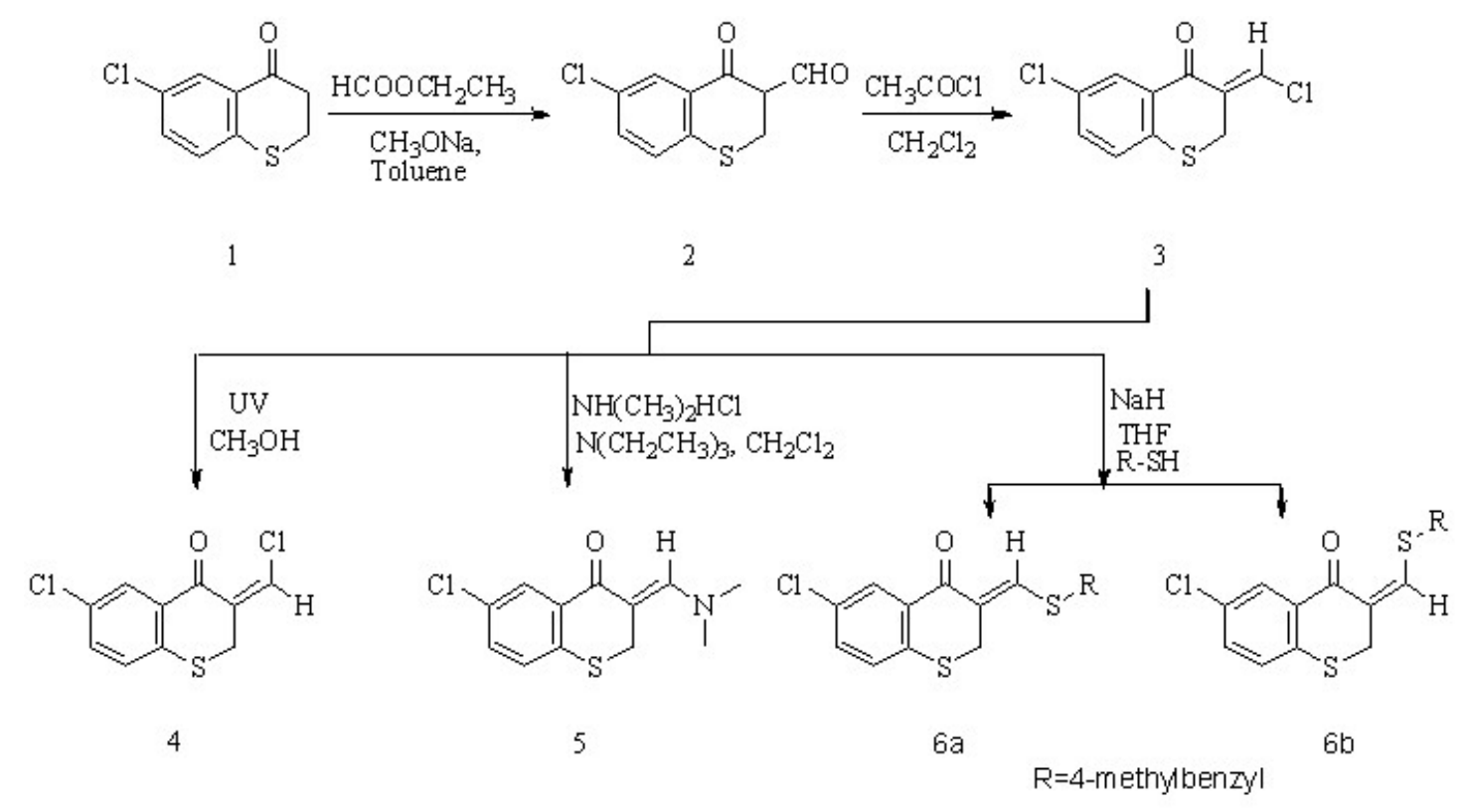

Scheme 1. The synthesis route of target compound

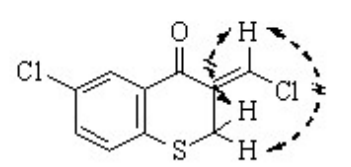

3<smiles>O=C1c2cc(Cl)ccc2S[C@H]2C=CCC=CC12</smiles>

4

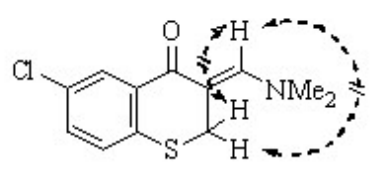

5<smiles>CC[C@@H]1Sc2ccc(Cl)cc2C(=O)/C1=C/Sc1ccc(C)cc1</smiles>

$6 \mathrm{~b}$

Figure 1. NOE correlations are shown by arrows 


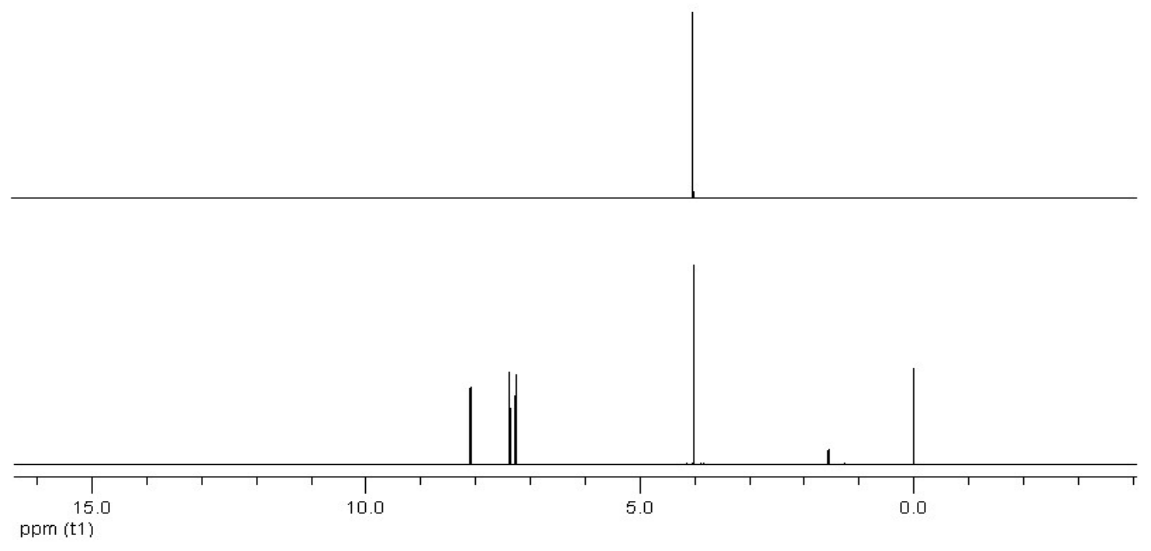

compound 3 .

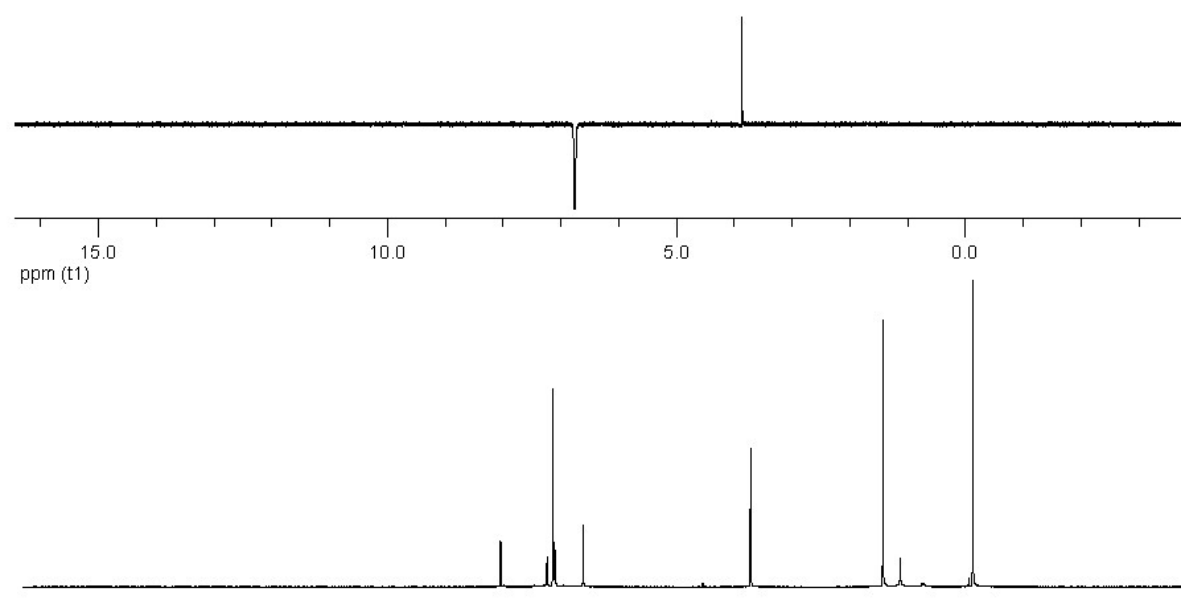

compound 4.

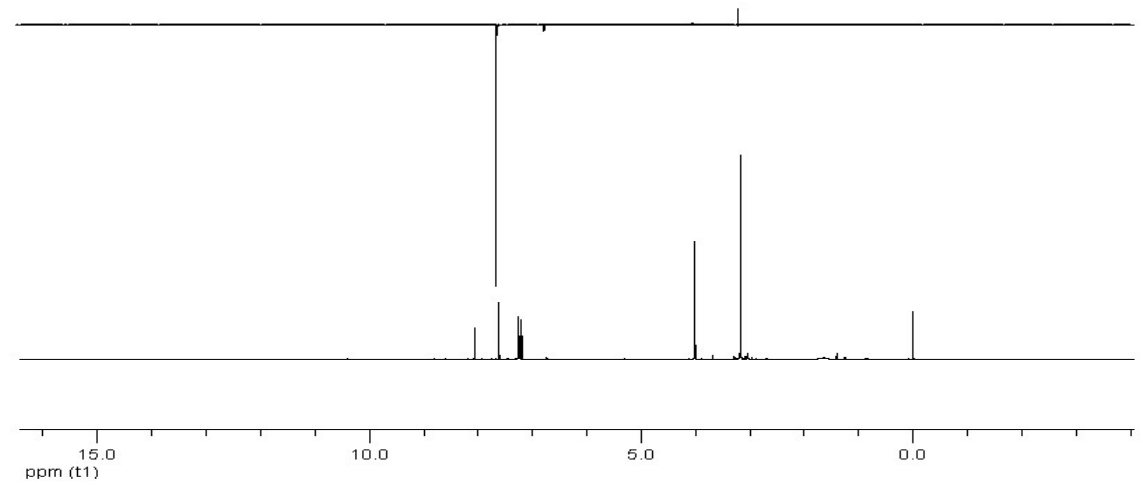

compound 5. 


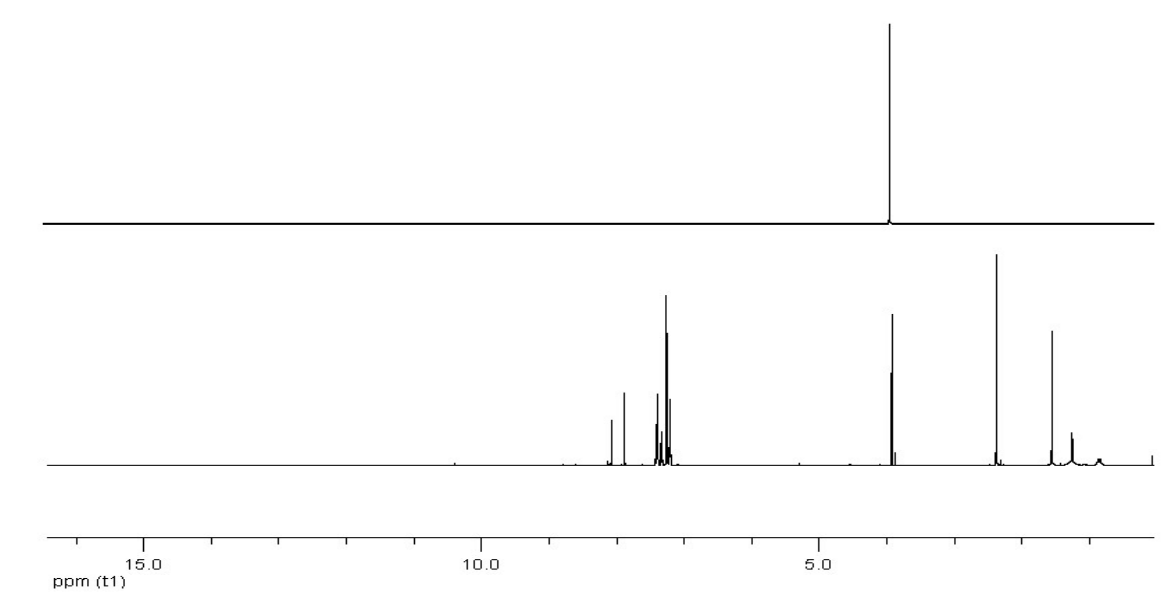

compound 6a.

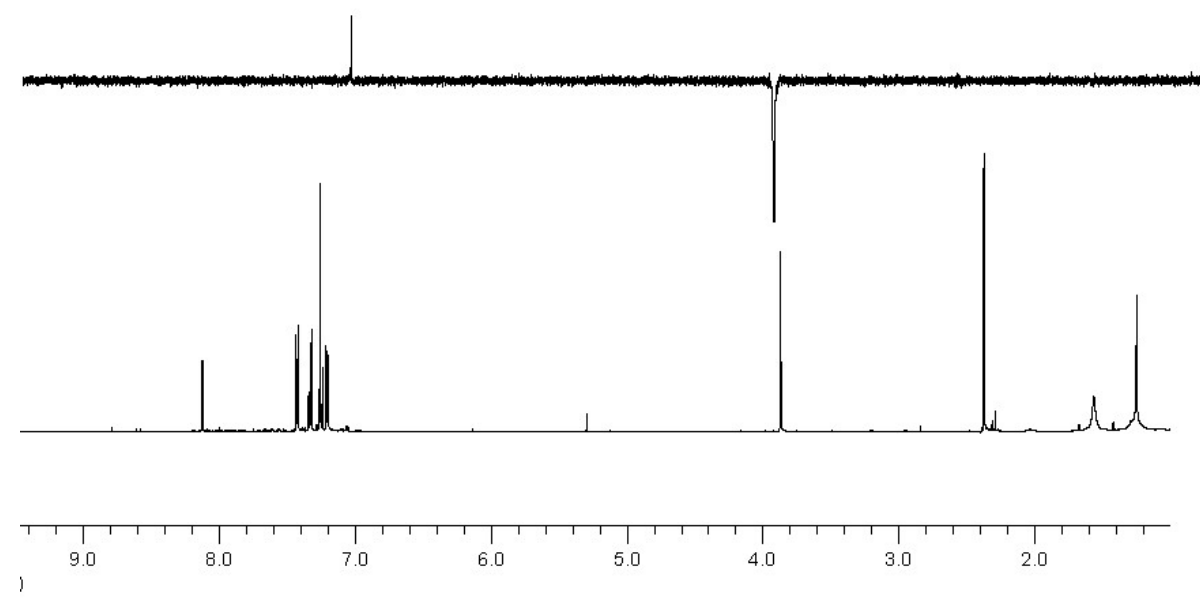

compound $6 b$.

Figure 2. ${ }^{1} \mathrm{H}$ NMR spectral and NOE spectral of 3a, 4, 5 and 6 